\title{
Correction to: Can cord blood sampling delay the first packed red blood cell transfusion?
}

\author{
Rupin Kumar $[$ B Brynne Sullivan
}

Published online: 4 November 2021

(c) The Author(s), under exclusive licence to Springer Nature America, Inc. 2021

Correction to: Journal of Perinatology

https://doi.org/10.1038/s41372-020-00872-z

Following online publication of this article, it was noticed that the citation to the original article was omitted. The citation is provided below. The original article has been corrected.
Manuscript citation: Balasubramanian $\mathrm{H}$, Malpani $\mathrm{P}$, Sindhur M, et al. Effect of Umbilical Cord Blood Sampling versus Admission Blood Sampling on Requirement of Blood Transfusion in Extremely Preterm Infants: A Randomized Controlled Trial. J Pediatr. 2019; 211.

Publisher's Note Springer Nature remains neutral with regard to jurisdictional claims in published maps and institutional affiliations. 